\title{
BM] Global Health Terrorist attack of 15 January 2016 in Ouagadougou: how resilient was Burkina Faso's health system?
}

\author{
Valéry Ridde, ${ }^{1}$ Lucie Lechat, ${ }^{2}$ Ivlabehire Bertrand Meda ${ }^{3}$
}

To cite: Ridde V, Lechat $L$, Meda IB. Terrorist attack of 15 January 2016 in Ouagadougou: how resilient was Burkina Faso's health system?. BMJ Global Health 2016;1:e000056. doi:10.1136/bmjgh-2016000056

Received 4 April 2016 Revised 1 June 2016 Accepted 20 June 2016

\section{CrossMark}

\author{
${ }^{1}$ University of Montreal Public \\ Health Research Institute - \\ (IRSPUM) and University of \\ Montreal School of Public \\ Health (ESPUM), Québec, \\ Canada \\ ${ }^{2}$ AGIR/IRSPUM \\ ${ }^{3}$ IRSS/CNRST, Ouagadougou, \\ Burkina Faso
}

Correspondence to Professor Ridde Valéry; valery.ridde@umontreal.ca

\section{ABSTRACT}

In Africa, health systems are often not very responsive. Their resilience is often tested by health or geopolitical crises. The Ebola epidemic, for instance, exposed the fragility of health systems, and recent terrorist attacks have required countries to respond to urgent situations. Up until 2014, Burkina Faso's health system strongly resisted these pressures and reforms had always been minor. However, since late 2014, Burkina Faso has had to contend with several unprecedented crises. In October 2014, there was a popular insurrection. Then, in September 2015, the Security Regiment of the deposed president attempted a coup d'état. Finally, on 15 January 2016, a terrorist attack occurred in the capital, Ouagadougou. These events involved significant human injury and casualties. In these crises, the Burkinabè health system was sorely tried, testing its responsiveness, resiliency and adaptability. We describe the management of the recent terrorist attack from the standpoint of health system resilience. It would appear that the multiple crises that had occurred within the previous 2 years led to appropriate management of that terrorist attack thanks to the rapid mobilisation of personnel and good communication between centres. For example, the health system had put in place a committee and an emergency response plan, adapted blood bank services and psychology services, and made healthcare free for victims. Nevertheless, the system encountered several challenges, including the development of framework documents for resources (financial, material and human) and their use and coordination in crisis situations.

\section{HEALTH CRISES TESTING THE RESILIENCE OF HEALTH SYSTEMS IN AFRICA}

The Ebola outbreak in West Africa was a stark reminder of the importance of ensuring health systems' capacity to contend with a health crisis. In other words, it underscored yet again the concept of health system resilience. $^{1-3}$ Of course, this concept is neither new nor original, nor even specific to Africa; we have only to recall Texas in the USA, ${ }^{1}$ or France, where more than 15000 people perished in the heat wave of $2003^{4}$ when the health system, taken in the broadest sense, ${ }^{5}$
Key questions

What is already known about this topic?

- The concept of health system resilience is still new.

- Health systems in West Africa are precarious, not very responsive, and dysfunctional.

- Terrorist attacks in Africa are increasing and pose challenges for health systems.

What are the new findings?

- Burkina Faso's health system has always made marginal changes, without major reforms.

- The series of political and terrorist events since 2014 have prompted the actors to adapt.

- The continuity of medical and psychological services provided, and their continued provision free of charge, should be monitored.

Recommendations for policy

- A crisis response plan should be formulated and put in place.

- Health personnel should be better trained to manage crises.

Healthcare facilities need to be better prepared.

was unable to cope with this shock. In West Africa, however, we know health systems are precarious, with significant and recurrent dysfunctions, ${ }^{6}$ inadequate funding, insufficient numbers of health personnel, and continued poor responsiveness to the needs of patients and citizens. ${ }^{5} 78$ The recent Ebola epidemics and the Lassa crisis in Benin in 2014 (resurging in 2016) have sorely tested the resilience of these health systems. ${ }^{9}$

\section{The historical 'muddling through' strategy of Burkina Faso's health system reforms}

Burkina Faso's health system might be an exception in the region. Indeed, it appears that, for the time being, it has managed to cope with the many crises that have erupted in its history, ${ }^{10}$ even though its effectiveness and equity continue to be of concern, as the use of services is low, especially among the poorest. ${ }^{11}$ 
The health system has always adapted to multiple reforms, although without fundamentally changing or taking any great risks. For example, it opted for a subsidy for assisted deliveries rather than an exemption, in contrast to Ghana and Senegal. ${ }^{12}$ It was one of the last countries to abolish fees for antiretroviral (ARV) therapy, whereas Senegal had taken the lead 10 years earlier. ${ }^{13}$ It chose to test results-based financing, like neighbouring Benin and Mali, but also remained focused on demand and on user-fees exemptions for indigents. ${ }^{14}$ It developed a regionalised approach to human resources recruitment, ${ }^{15}$ in contrast to Niger, for example, where recruitment is still centralised. To minimise shocks and thereby to test the resilience of its system, Burkina Faso has most often opted instead for a 'muddling through' strategy, as political analysts would say. ${ }^{16}$

However, this business-as-usual approach is often seen as worrisome by civil society organisations, who would like more actions and changes along the lines, for instance, of Amnesty International's decision to become involved in the fight against maternal mortality, ${ }^{17}$ even though this is outside its usual sphere.

Likewise, the Burkinabè health system has always managed to deal with major epidemics (meningitis, measles) without collapsing. Thus, in 1996, the meningitis epidemic, which had been recurrent since at least 1980, affected 42967 people, and for the first time its lethality exceeded $10 \%$. Since then, the health system appears to have adjusted to this new lethality, which has sometimes reached as high as $20 \%$, as well as to a new strain, W135, that first emerged in 2002. ${ }^{18}$

Burkina Faso's health system appears resilient, or at least able to adapt itself. However, it does not seem to be prepared to cope with crises that are not part of its usual activities. For example, seasonal epidemics of dengue fever are most often overlooked because the key actors (particularly funding agencies and decision-makers) are focused on malaria. Dengue was not made a notifiable disease until 2012, even though the virus first emerged in 1925 in that country. ${ }^{19}$ Generally speaking, neither the surveillance system nor the health system was really prepared to deal with Ebola and haemorrhagic fevers, ${ }^{20}$ and health workers even questioned the state's capacity for action on this front. $^{21}$ This leads us to hypothesise that the Burkinabè health system has thus far been fortunate not to have experienced any significant sustained crises that could overwhelm it, such as a major epidemic or a civil war.

\section{Recent crises in Burkina Faso and in Africa}

Since October 2014, Burkina Faso's health system has been confronted with three major events that have tested its responsiveness and adaptability in dealing with injuries and deaths. In late October 2014, a violent clash between the people and the government led to a popular insurrection that resulted in 24-33 deaths, depending on sources, and more than 600 persons wounded across the country (Observateur Paalga, 4 December 2014) in demonstrations against the security forces. In September 2015, an attempted coup d'état by the security regiment of the deposed president took a heavy human toll. The prime minister at the time reported 14 deaths and 251 persons wounded (Agence de Presse Africaine, 7 October 2015). More recently, on Friday, 15 January 2016, a terrorist attack occurred in downtown Ouagadougou, the country's capital. The press reported 30 deaths and at least 71 persons wounded (Journal Le Pays, 20 January 2016). This was, in fact, the first such event in Burkina Faso, although terrorist attacks have been on the rise in African countries, such as Nigeria, Cameroon, Chad and even Kenya. Thus, West Africa, and notably the Sahel region, is no longer spared from the threat of terrorism. On 20 November 2015, a terrorist attack in Mali's capital, Bamako, resulted in 22 deaths and 9 wounded. On 13 March 2016, another terrorist attack on the famous beaches of Cote d'Ivoire resulted in 19 deaths (Radio France Internationale (RFI), 21 March 2016). In Nigeria, the number of victims in 2015 was calculated to be around 3500 (Jeune Afrique, 31 Dec 2015). On the entire African continent, also in that year, 4523 victims of deadly attacks were reported in 44 of the 54 countries (Le Monde, 8 January 2016). Nigeria is one of the three countries most often attacked, the others being Sudan and Somalia, with attacks by Boko Haram being the primary cause of deaths in $2015 .^{22}$

In this commentary, we describe the events in Burkina Faso and how the health system reacted to this series of unprecedented events that were outside its control. Our analysis is based on our knowledge of the context, our presence at the time of these events, and meetings with key actors. We conducted informal interviews with managers of healthcare facilities and clinical services that treated the injured and with persons from international cooperation agencies and non-governmental organisations (NGOs). Manual thematic content analysis was performed on the interview data. We also reviewed the local and international press coverage.

\section{THE CONTEXT OF BURKINA FASO AND OF THE HEALTH SYSTEM IN ITS CAPITAL OUAGADOUGOU}

Burkina Faso is one of the region's poorest countries. The current health system is the product of numerous reforms, notably since the 1980s, when it was organised into districts and point-of-service user fees were implemented countrywide. ${ }^{10} 12$ Less than $2 \%$ of the population is covered by health insurance, and the health system's overall performance is weak. ${ }^{23}$ Service provision is based on a pyramid structure, with CSPSs (Centre de Santé et de Promotion Sociale) at the base, which provide primary care, then district hospitals (Centre Médical avec Antenne Chirurgicale, CMA), regional hospitals (Centre Hospitalier Régional, CHR), and finally national hospitals (Centre Hospitalier Universitaire, CHU).

The population of Ouagadougou, the capital, is estimated to be $2532311 .^{24}$ Provision of healthcare has long been 
the exclusive responsibility of the state, and the healthcare system has evolved with the city, undergoing rapid urban spread. ${ }^{25}$ Since 1993, the private sector has invested heavily in providing services, particularly in urban areas. ${ }^{26}$ In 2010 , there were 327 health centres in the centre region, of which 171 were for-profit private centres. ${ }^{27}$

\section{The terrorist attack and the health system's resilience}

On 15 January of this year, the terrorist attack began at about 19:40 in the city centre, on a very busy avenue of the capital (Kwame N' Kruma Avenue). Assailants strafed a bar and a café-restaurant, both very popular sites in the capital, with machine guns. They set fire to some vehicles that then exploded, then shut themselves into a hotel that also partially caught fire, taking the residents hostage.

In November 2015, after the Bamako attack, the French and Burkinabè forces had begun working on a 'Red Plan' to contend with such an attack, but in January the plan was not finished and the organisers had not yet met with all the parties involved. In the event of an attack involving a large number of victims, the Red Plan was intended to organise first-response care to treat victims rapidly and effectively. The Brigade Nationale des Sapeurs Pompiers (BNSP), assisted by French firefighters, arrived rapidly at the scene of the attack. All the fire stations' equipment and personnel were deployed to the site, including the entire contingent of ambulances and person available at that time, although we were unable to ascertain their exact numbers. The Red Cross dispatched 19 rescue workers and three ambulances. The Order of Malta and the Cooperation française healthcare facility (Centre Médical International, CMI) each dispatched an ambulance. However, they only began evacuating people after security forces had secured the perimeter, about 2 hours after the attack had started. The injured were transported gradually as they were extricated from the combat zones, and the ambulances went back and forth to the hospitals many times, especially since the main hospital was located only 10 min away from the attack site.

According to the local press, those who had been severely injured and shot were transported to the main university hospital, the CHU-Yaldago Ouédraogo (CHU-YO). Those with less serious injuries and psychological trauma were brought to the city's other hospital, the CHU-Blaise Compaoré (CHU-BC), or to secondarycare facilities (RFI, 17 January 2016). The allocation of patients appeared to have been done after a triage at the scene of the attack. This triage was performed by both Burkinabè fire chiefs and a manager from the CMI. Patients were triaged based on prognosis and severity of injury. The country's main hospital, the CHU-YO, received most of the injured $(n=32)$. However, some of the injured were later transferred to other health facilities for a variety of reasons, such as medical staff decisions or patients' requests. Hence, a patient with a bullet wound to the thorax and another with an open fracture were transferred to the CHU-BC, which had a specialist in thoracic surgery. That hospital also received around 20 patients suffering from smoke inhalation and from psychological trauma who were directly evacuated from the attack site. The hospital of a military camp (Camp Guillaume) was sent a patient with a fracture from CHU-YO, probably because the patient was a soldier. The CMA of Sector 30 received less seriously injured patients. A private clinic (Notre Dame de la Paix) received a patient with a bullet wound (a French-Moroccan photographer), who had to be evacuated. Finally, the CMI received two patients with psychological trauma and one with respiratory distress. Only one injured person died after admission to a private hospital (we did not learn the cause of death), and none of the injured were evacuated outside the country. These transfers from one health centre to another showed the centres' complementarity and how the health system was able to cope.

\section{Health centre responsiveness: lessons drawn from the past but not yet applied}

The press noted that, 'The crisis management committee of the hospital was activated when the first injured patients began flooding in' (LeFaso.net, 16 January 2016). This committee was, in fact, born on the night of the attack and has been maintained and continues to evolve. The previous crises had been managed by ad hoc committees. This time, the CHU-YO wanted to put in place a permanent committee, made up of three commissions: medical, medicotechnical and administrative. Plans are under way to develop procedure manuals for use in such events. Meanwhile, it was the hospital's executive director who coordinated the management of the injured, and the on-call personnel were sufficient to treat them, as there were fewer injured this time than in the two previous crises. The teams at the CHU-BC appeared to be better prepared for this type of event. That hospital has a 'White Plan' (not yet approved) and a crisis committee with procedures to follow in emergency situations. The White Plan is a tool similar to the Red Plan, but it deals with the organisation of services provided after the first-response care. Following the insurrection, the hospital leadership created the crisis committee, made up of the directors of all the clinical services and the managers of technical services. That committee had met when the coup d'état occurred to coordinate management of the injured, thereby testing the White Plan unexpectedly. These tools were very useful in that situation (period of insecurity and curfews), in which it was very difficult to requisition personnel. Certain solutions came out of that experience, such as setting up a transportation system using hospital ambulances to fetch personnel from their homes and a call centre to advise personnel on the safest routes to travel to the hospital. These were issues that had not been considered when the White Plan was developed. When that plan was put to the test in the coup d'état, they were able to draw lessons from the experience, which will contribute to the tool's construction. Neither 
the White Plan nor the crisis committee was activated on 15 January because, when the first cases arrived, the teams were on site and ready, and there were fewer injured than in the two earlier crises. This difference in the two hospitals' preparedness could be due to the fact that the CHU-BC, being more recent, is more modern in terms of infrastructure and management.

The Centre National de Transfusion Sanguine (CNTS) rapidly took special measures to respond to the situation. Usually on weekends the CNTS is only open on Saturdays from 07:00 to 12:00 for blood donations, but on Saturday and Sunday, 16th and 17th January, it remained open from 07:00 to 17:00 to process a fortuitous influx of donors generated by social media appeals launched by individuals acting on their own. In those 2 days, the CNTS collected (on its premises) 112 bags of blood and then another 94 bags on 18 January, a significant increase over the usual average of 30 bags per day. This was not in response to any need for blood expressed by the hospitals or the CNTS, but rather to the initiatives of isolated citizens who believed there would be a need. Such appeals had already been observed in the coup d'état of November 2014. At that time, donors were turned away because the CNTS was not prepared to collect blood outside its usual hours of operation. This led to sharp criticism of the CNTS on social media. Having learnt from these events, this time it reacted by putting blood collection teams in place even though it was not the source of the appeal for donors.

\section{Psychological management}

Two psychological cells were created on the day after the attack: one in the psychiatry service of the CHU-YO and the other in a youth centre in the city, which functioned for 1 week. The second site was selected because of its geographic location, functional capacities and popularity. Victims of the attack, their families and friends, and witnesses (people living near the attack sites) either went there on their own or were brought there, beginning in the first hours of the attack. Psychologists in the city were available there for consultations. A toll-free telephone number was set up for basic information on consultation services. This number is still in effect and the service is still receiving calls. Callers are referred to the hospital's psychiatry service. According to the assistant coordinator of the medicopsychological cell, thus far 187 persons have been treated, either at the hospital or at home, and the work is ongoing (Yalgado Info N.,14January 2016).

This map inventories the health services and the two psychological medical centres (figure 1). It explains the distribution of both the physically injured and those

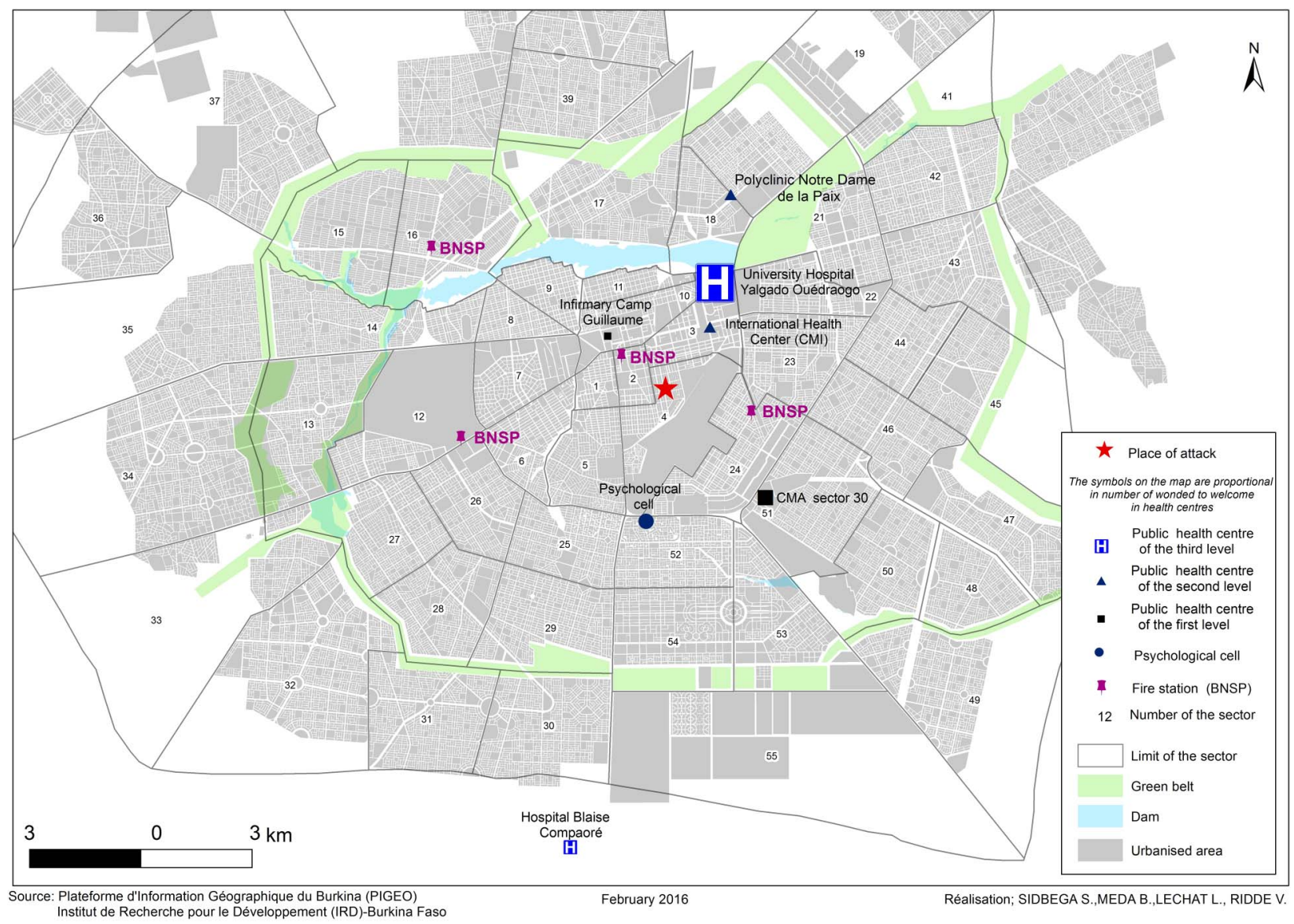

Figure 1 Map of emergency response and health services structures mobilised during the 15 January 2016 terrorist attack in Ouagadougou. BNSP, Brigade Nationale des Sapeurs Pompiers; CMA, Centre Médical avec Antenne Chirurgicale. 
with psychological injuries. Secondary transfers of the injured between healthcare facilities occurred subsequently; as such, two different healthcare facilities could have received the same patient on that day.

\section{Involvement of local and international solidarity}

Three medical NGOs and one local medical organisation provided assistance on the night of the attack. They are considered part of the health system and are authorised by the state to intervene. These were organisations that had intervened at the time of the insurrection and the coup d'état: the Red Cross, the Order of Malta, Alima and the CMI. Besides the on-site ambulatory assistance provided by some of these organisations to transport the injured, they also provided material assistance. The CMI and the Order of Malta provided boxes of gloves and disinfectant gel to some firefighters of the BNSP who had requested them. At the CHY-YO, the Red Cross and Alima donated medicotechnical materials and medicines. Finally, the Red Cross brought medicines and consumable supplies to the CHU-BC. Individuals also made donations, as in the previous crises.

\section{Taking charge of the financial aspects: costs of medical services fully covered}

In the days following the attack, the CHU-YO's executive director announced that, 'On instructions from the government, all the wounded who came in will be treated free of charge' (LeFaso.net, 16 January 2016), a strategy that appears to have been fundamental in Nigeria in the context of terrorist attacks there. ${ }^{28}$

Thus, a Ministry of Health press release was distributed through local media (television, radio, newspapers). Healthcare providers were instructed to note 'victim of attacks' on prescriptions, which would then allow those victims' families to obtain the medicines free of charge from the hospitals' pharmacies. In cases where injured persons had already paid for services, they were to be reimbursed by the hospital management on presentation of receipts and prescriptions showing the complete identity of the prescribing agent. It may be recalled that, following the prime minister's visit on 4 November 2014, hospitals were instructed to reimburse the fees paid by victims of the insurrection for consultations and prescriptions beyond their immediate emergency care (Yalgado Info Number 14, published January 2016). These free services are to be covered initially by the hospital's own funds, with the expenses to be sorted out later at the Ministry of Health for reimbursement.

However, it is not clear whether this free coverage applies only to care provided in emergency rooms or extends to all services until the patient has fully recovered. According to a hospital administrator, the government's understanding is that the free coverage is only for emergency services. In practice, however, patients are treated at no charge until they have fully recovered. That is what was done for the victims of the insurrection and the coup d'état, and it is this policy that both hospitals intend to apply for the victims of the January attack.

With regard to free care, one aspect does not yet appear to have been considered: the management of victims who present with psychological problems at some point after the attacks. Indeed, according to the coordinator of the medicopsychological cell, it is to be expected that some victims, or even witnesses to the attack, who did not originally feel any need to seek out care, could present with certain psychiatric pathologies after several months. Will they receive free care? In this case, how will the hospitals differentiate them from patients who have nothing to do with the terrorist attack?

\section{CRISIS UNDER CONTROL BUT QUESTIONS REMAINING}

In Burkina Faso, it appears that the different crises the country has undergone since 2014 have enabled the health system, at least in its capital city, to cope with the January 2016 attack. From an exploratory perspective, table 1 summarises the five dimensions of a resilient system proposed by Kruk et $a l^{1}$ as they apply to the particular situation of Burkina Faso. An in-depth study would be needed to supply the rigorous empirical data needed to substantiate this table.

Table 1 The five dimensions of resilience as applied to the health system of Ouagadougou, Burkina Faso

\begin{tabular}{|c|c|}
\hline Aware & $\begin{array}{l}\text { Good health information system } \\
\text { Unexpected terrorist attack } \\
\text { Security force and health professionals } \\
\text { poorly prepared } \\
\text { being formulated, not yet implemented }\end{array}$ \\
\hline Diverse & $\begin{array}{l}\text { Pyramidal (public/private) health system } \\
\text { effective in the capital } \\
\text { Good network of primary care health } \\
\text { centres and university hospitals } \\
\text { Very high density of health professionals } \\
\text { and specialists in the capital } \\
\text { - Slow reaction to new threats }\end{array}$ \\
\hline Self-regulating & $\begin{array}{l}\text { Capital oversupplied in healthcare } \\
\text { facilities and health professionals } \\
\text { Crises of relatively small scale in terms } \\
\text { of number of victims, not affecting } \\
\text { routine services } \\
\text { Services most concerned adapted } \\
\text { themselves (eg, CNTS) }\end{array}$ \\
\hline Integrated & $\begin{array}{l}\text { Communication and information sharing } \\
\text { improved from one crisis to the next } \\
\text { Information disseminated by traditional } \\
\text { and social media } \\
\text { Civil society and NGOs mobilised in } \\
\text { context of significant social change }\end{array}$ \\
\hline Adaptive & $\begin{array}{l}\text { Hours of CNTS operation modified } \\
\text { Several healthcare facilities and medical } \\
\text { NGOs mobilised }\end{array}$ \\
\hline
\end{tabular}

CNTS, Centre National de Transfusion Sanguine; NGOs, nongovernmental organisations. 
If we consider the three categories of resilience, ${ }^{29}$ it appears, in fact, that the system in Burkina Faso was able to absorb the Ouagadougou crisis, to adapt to the situation, and to respond by providing the services victims required, even if many questions remain.

So, there are still two matters to be resolved. The first is how the management of recent or potential victims will be organised and continued, since even after three successive crises it appears that no clear solution has yet been proposed. The second is the actual implementation of the Red Plan, which needs to be prepared and applied as soon as possible. Even so, health and emergency response personnel and authorities mobilised rapidly to rescue victims and to coordinate their efforts, thanks especially to a good communication system. They definitely had all learnt from the previous crises. However, our analysis needs to be put into perspective: while any loss of life is tragic, the scope of the shocks that Burkina Faso's health system endured was relatively limited and certainly more psychological than organisational. While no one would wish to see it tested, we cannot predict how the system might react to a major crisis, such as Ebola might have been in $2014,{ }^{20}$ for example, and especially outside the capital.

Our analysis highlights several important lessons for responding effectively to such crises: set up crisis management committees in the main hospitals; communicate swiftly and clearly to mobilise health personnel; anticipate needs and communicate with the public; provide training to improve triage at both emergency centres and health facilities; and define the needs and build on them. Still, many questions remain.

Since this article is essentially descriptive, we believe an in-depth study should be conducted as soon as possible to better understand, grasp, and improve the health system's resilience and ability to cope with major shock. What was it about the actors, the health system and the context that fostered a process of resilience that appears to have been effective?

\section{Handling editor Seye Abimbola}

Twitter Follow Valéry Ridde at @ValeryRidde and Lucie Lechat at @Lechatlucie

Acknowledgements The authors wish to thank everyone they encountered in Ouagadougou for taking the time to share with them their experiences of these tragic events. They also wish to thank Emmanuel Bonnet, Esther McSween, Linda François, Ludovic Queuille and the three anonymous reviewers for their feedback on a previous version of this article. They also thank Donna Riley for translation and editing support. VR holds a CIHRfunded Research Chair in Applied Public Health (CPP-137901).

Contributors VR designed the idea with the support of LL and IBM. He drafted the paper and revised it with the support of $L L$ and IBM. LL and IBM collected the data in Ouagadougou and LL did the map. All the authors reviewed and approved the manuscript.

Funding Institute of Population and Public Health, 10.13039/501100000036, CPP-137901.
Competing interests None declared.

Provenance and peer review Not commissioned; externally peer reviewed.

Data sharing statement No additional data are available.

Open Access This is an Open Access article distributed in accordance with the Creative Commons Attribution Non Commercial (CC BY-NC 4.0) license, which permits others to distribute, remix, adapt, build upon this work noncommercially, and license their derivative works on different terms, provided the original work is properly cited and the use is non-commercial. See: http:// creativecommons.org/licenses/by-nc/4.0/

\section{REFERENCES}

1. Kruk ME, Myers M, Varpilah ST, et al. What is a resilient health system? Lessons from Ebola. Lancet 2015;385:1910-12.

2. Malik K. Human Development Report 2014. Sustaining Human Progress: Reducing Vulnerabilities and Building Resilience. New York: United Nations Development Programme, 2014. http://hdr.undp.org/sites/default/files/hdr14-report-en-1.pdf (accessed 17 Feb 2015).

3. European Commission. On effective, accessible and resilient health systems. Brussels: EC, 2014. http://ec.europa.eu/health/healthcare/ docs/com2014_215_final_en.pdf (accessed 23 Mar 2016).

4. Abenhaim L. Canicules: La santé publique en question. Paris: Fayard, 2003.

5. WHO. The World Health Report 2000-Health Systems: Improving Performance. Geneva: World Health Organization, 2000.

6. Jaffré Y, Olivier de Sardan JP, eds. Une médecine inhospitalière. Les difficiles relations entre soignants et soignés dans cinq capitales d'Afrique de l'Ouest. Paris: APAD, Karthala, 2003.

7. WHO. World Health Report 2013: Research for Universal Health Coverage. Geneva: World Health Organization, 2013.

8. Abiola SE, Gonzales R, Blendon RJ, et al. Survey in sub-Saharan Africa shows substantial support for government efforts to improve health services. Health Aff (Millwood) 2011;30:1478-87.

9. N'koué Sambiéni $E$, Danko $N$, Ridde $V$. La fièvre hémorragique à virus Lassa au Bénin en 2014 en contexte d'Ebola: une épidémie révélatrice de la faiblesse du système sanitaire. Anthropologie \& Santé 2015. Published Online First 9 Nov 2015. doi:10.4000/ anthropologiesante.1772

10. Meunier A. Système de soins au Burkina Faso. Le paradoxe sanitaire. Paris: L'Harmattan, 2000.

11. INSD, Measure DHS, ICF Macro. Enquête démographique et de santé et à indicateurs multiples (EDSBF-MICS IV), Rapport préliminaire, Burkina Faso, 2010. Ouagadougou: Institut National de la Statistique et de la Démographie, 2011.

12. Ridde V. From institutionalization of user fees to their abolition in West Africa: a story of pilot projects and public policies. BMC Health Serv Res 2015;15(Suppl 3):S6.

13. Kouanda S, Bocoum FY, Doulougou B, et al. User fees and access to ARV treatment for persons living with HIV/AIDS: implementation and challenges in Burkina Faso, a limited-resources country. AIDS Care 2010;22:1146-52.

14. Ridde V, Turcotte-Tremblay AM, Souares A, et al. Protocol for the process evaluation of interventions combining performance-based financing with health equity in Burkina Faso. Implement $\mathrm{Sci}$ 2014;9:149.

15. Kouanda S, Yaméogo WM, Ridde V, et al. An exploratory analysis of the regionalization policy for the recruitment of health workers in Burkina Faso. Hum Resour Health 2014;12:S6.

16. Sabatier PA, Weible CM, eds. Theories of the policy process. 3rd edn. Boulder, CO: Westview Press, 2014.

17. Amnesty International. Giving life, risking death: maternal mortality in Burkina Faso. London: Amnesty International Publications, 2009.

18. Ministère de la Santé. Annuaire serie longue de la santé. Ouagadougou: Ministère de la Santé, Direction générale de l'information et des statistiques sanitaires, 2011. http://www.cns.bf/ IMG/pdf/dgiss_annuaire_serie_longue.pdf (accessed 23 Feb 2016).

19. Ridde V, Agier I, Bonnet E, et al. Presence of three dengue serotypes in Ouagadougou (Burkina Faso): research and public health implications. Infect Dis Poverty 2016;5:23.

20. Munoz M, Ridde V, Yaro S, et al. Beyond Ebola: surveillance for al hemorrhagic fever in West Africa should be enhanced. Pan Afr Med J 2015;22(Suppl 1):3.

21. Østergaard LR. Ebola vu de loin: les agents de la santé face au risque et à l'incertitude dans les campagnes du Burkina Faso. 
Anthropologie \& Santé 2015. Published Online First 30 Nov 2015. doi:10.4000/anthropologiesante.1833

22. Pérouse de Montclos MA. Nigeria Watch Project: Fifth Report on Violence (2015). Abuja: Nigeria Stability and Reconciliation Programme, 2016.

23. Agier I, Ly A, Kadio K, et al. Endorsement of universal health coverage financial principles in Burkina Faso. Soc Sci Med 2016;151:157-66.

24. INSD. Projections démographiques de 2007 à 2020. Ouagadougou: Ministère de l'économie et des finances, Institut national de la statistique et de la démographie, 2009.

25. Cadot E, Harang M. Offre de soins et expansion urbaine, conséquences pour l'accès aux soins. L'exemple de Ouagadougou (Burkina Faso). Espace Popul Sociétés Space Popul Soc 2006;23:329-39.

26. Harang M. Système de soins et croissance urbaine dans une ville en mutation: le cas de Ouagadougou (Burkina Faso) [Doctoral thesis]. Nanterre: Université de Paris. 2007. http://www. espace-sante-territoires.fr/THESE_M-HARANG.pdf (accessed 23 Mar 2016).

27. Institut de Recherche en Sciences de la Santé. Evaluation des Besoins en Soins Obstétricaux et Néonataux d'Urgence, couplée à la cartographie de l'offre de soins en Santé de la Reproduction au Burkina Faso. Ouagadougou: Ministère de la Recherche Scientifique et de l'Innovation, 2011. http://planificationfamiliale-burkinafaso.net/ docs/information/Evaluation\%20de\%20SONU\%20UNFPA.pdf (accessed 23 Mar 2016)

28. Ager AK, Lembani M, Mohammed A, et al. Health service resilience in Yobe state, Nigeria in the context of the Boko Haram insurgency: a systems dynamics analysis using group model building. Confl Health 2015;9:30.

29. Kutzin J, Sparkes SP. Health systems strengthening, universal health coverage, health security and resilience. Bull World Health Organ 2016;94:2. 